\author{
축산 · =의분야의 델파이 기술예측조사에 관한 연구 \\ 조근태* . 백인기** . 조영우*** . 이종인*** \\ 성균관대학교 시스템경영공학부*, 중앙대학교 동물자원과학과**, 농림기술관리센터***
}

\title{
A Study on Survey for Technology Forecasting using Delphi in Animal Science and Veterinary Medicine
}

\author{
K. T. Cho*, I. K. Paik**, Y. W. Cho*** and J. I. Lee*** \\ School of Systems Management Engineering, Sungkyunkwan University, Suwon 440-746, Korea*, \\ Department of Animal Science, Chung-Ang University, Ansung 456-756, Korea**, \\ ARPC, Seoul 134-010, Korea***
}

\begin{abstract}
The study was designed to forecast and derive future core technologies using Delphi method for Korean livestock industry. The technologies will make livestock industry a core and strategic industry that has high value-added sector in 21 century. Questions were given to specialists of each technology in order to survey importance, realization time, level of $R \& D$ in Korea and foremost countries, leading group of $R \& D$, effective policy, etc. for each technology. The target of the survey for Delphi is confined to specialists in the area of Animal Science and Veterinary Medicine. 90 core technologies were derived and 62 specialists answered the questionnaire.
\end{abstract}

(Key words : Delphi Method, Technology Forecasting)

\section{I 서 론}

산업과 기술이 발달함에 따라 국가, 부문, 또 는 산업차원에서 기술 및 지식가치의 역할이 증대되고 기술보호주의가 심화되고 있다. 기술 혁신이 국가 및 산업경쟁력을 좌우하는 중요한 원천으로 부각이 되고 있기 때문이다. 이에 따 라, 기술수요조사 및 예측, 기술로드맵 작성, 그리고 자원배분 등 기술개발에 대한 사전기획 의 역할이 점차 확대되고 있다. 특히, 국가연구 개발사업 연구관리차원에서의 주안점에 대한 패러다임 역시 객관적 연구과제의 선정 - I도 관리. !과관리 중심에서 기술수요조사 및 예 측, 자원배분 등 사전기획과 기술이전 등 성과 활용을 중요시하는 방향으로 변화하고 있는 추
세에 있다.

한편, 농업관련기술은 생명공학, 메카트로닉 스, 정보통신 등 타 분야의 첨단기술이 농업분 야에 접목이 되면서 첨단기술에 대한 수요가 점차 증대되고 있다. 이에 따라, 연구개발비, 연구인력, 연구시설 등 한정된 자원을 선택과 집중의 원칙에 따라 효율적. 릭럭으로 기술 개발에 투자할 수 있는 방안을 모색할 필요가 제기되고 있다. 급변하는 농업생명기술에 적절 하게 대처하기 위하여 정부에서는 농업분야 국 가연구개발투자를 2001년 일반예산의 3.3\%에서 2004년에는 일반예산의 5\%까지 확대할 계획이 지만 미래에 대한 정확한 산업 및 기술방향의 부재로 자원의 전략적 · | 중적 투자에 한계를 느끼고 있다.

Corresponding author : Jong-In Lee, Agricultural R\&D Promotion Center, Dongwha Building 5th Floor, 318 Gildong, Kangdonggoo, Seoul 134-010, Republic of Korea, CP :016-9347-4123, E-mail : ljongin@empal.com 
따라서, 농업이 21세기 고부가가치의 핵심전 략산업으로 발전할 수 있도록 미래에 유망한 기술을 예측. 눌하는 등 핵심기술의 수요를 파악함으로써 향후 효율적인 연구개발예산의 배분과 산업차원의 정보공유와 공동연구를 촉 진할 수 있는 방안을 마련할 필요가 제기되고 있다.

이를 위하여 본 연구에서는 기술예측 방법으 로 가장 광범위하게 사용되고 있는 델파이법 (Delphi Method)을 이용하여 축산 . =의분야의 미래유망기술의 실현시기, 중요도, 기술수준 등 에 대한 기술예측조사를 2 차에 걸쳐 실시하고 자 한다. 이 조사 결과를 이용하여 우리나라 축산 . =의분야의 미래유망기술을 알아보고 이 기술을 도달하기 위한 방법을 모색하고자 한 다.

\section{ㅍ 연구방법론}

델파이법은 미래에 실현될 주요 기술의 실현 시기, 중요도 등에 대하여 다수 전문가의 직관 을 수렴하는 기술예측의 한 방법으로 선진국은 물론 우리나라에서도 과학기술예측조사를 위해 유용하게 활용되고 있는 방법이다(Linstone and Turoff, 1975). 이 방법은 조사결과를 응답자에 게 제시하여 수정 응답할 기회를 부여함으로써 다수 전문가의 의견을 수렴할 수 있고, 또한 익명성의 보장으로 자신의 의견 및 주장을 자 유롭게 개진할 수 있도록 유도하여 다양한 정 보를 교환할 수 있는 장점이 있다(조와 권, 1999).

본 연구에서는 설문조사를 2회 시행하는 델 파이법을 이용하여 예측조사를 실시하였다. 설 문조사항목은 기술에 대한 전문도, 중요도, 실 현시기(국내 및 세계), 연구개발수준, 실현시기 의 확신도, 기술적으로 가장 앞선 국가, 연구개 발 추진주체, 유효한 정책수단 등 8개 항목을 선정하였다.

여기서, 중요도는 대, 중, 소로 구분하는데, ‘대'는 기술 및 사회, 경제적으로 매우 중요한 경우, ‘중’은 중요한 경우, ‘소'는 그리 중요하지 않은 경우이다. 이를 토대로 중요도지수를 도
출하는데, 중요도지수는 각 항목(r, 「 ‘ r \&」 r 필요」 ㅔㅔ 대한 가중치 $100,50,25,0$ 을 부여한다. 그 이유는 전체 응답자의 의견을 모 두 수용하기 위한 것으로 그 중 중요도 $r \mid\rfloor \mid$ 가중치를 더 준 것이다. 예를 들어 응답자 모 두가 중요도에 대해 r |, 고 응답했으면 그 중요도지수는 ‘ 100 ’이 되며, 모두 ‘ 필요」-고 응답했으면 중요도지수는 ' 0 '이 된다. 기술의 중요도 지수를 구하는 식은 다음과 같다.

중요도 지수

$$
I_{\text {index }}=-N_{\text {대 }} \times 100+N_{\text {중 }} \times 50+N_{\text {소 }} \times 25+N_{\text {불필요 }} \times 0
$$

여기에서,

$$
\begin{aligned}
& I_{\text {index }} \text { : 중요도지수 }\left(0 \leq I_{\text {index }} \leq 10\right) \\
& N_{\text {대 }} \text { : 중요도「|」! 응답자의 수 } \\
& N_{\text {중 }} \text { : 중요도「 ‘」! 응답자의 수 } \\
& N_{\text {소 }} \text { : 중요도「 ‘」! 응답자의 수 } \\
& N_{\text {불필요 }} \text { : 중요도「 필요」! 응답자의 수 } \\
& N_{\text {전체 }} \text { : 중요도「 체」 응답자의 수 }
\end{aligned}
$$

연구개발수준은 세계 최고수준대비 국내 연 구개발의 현 수준을 나타내며, 각 범위의 의미 는 다음과 같다.

연구개발수준비율 $\quad R_{j}=-\sum_{i=1}^{5} \frac{\left(O_{i} \times N_{j i}\right)}{O_{5} \times N_{j} \text { 전체 }}$ 여기에서,

$R_{j}: j$ 기술의 선진국 대비 국내 연구개 발 수준

$O_{i}$ : 국내 연구개발수준을 나타내는 각 범 위( $i$ )에 대한 순위통계량 ; 범위가 $0 \% \sim 20 \%, 21 \% \sim 40 \%, 41 \% \sim 60 \%$, $61 \% \sim 80 \%, 81 \% \sim 100 \%$ 일 때 $i$ 는 각각 $1,2,3,4,5$ 를 나타냄.

$N_{j i}$ : $j$ 기술의 각 범위에 해당하는 응답자 의 수 $\left(N_{i}=1,2,3,4,5\right)$

$N_{j \text { 전체 }}: j$ 기술의 전체 응답자 수 $\left(N_{j 1}+N_{j 2}\right.$ $\left.+N_{j 3}+N_{j 4}+N_{j 5}\right)$

델파이 설문조사를 위한 축산 - =의분야의 
기술을 선정하기 위해 문헌조사와 기술수요조 사를 병행하였다. 예를 들어, r -림기술개발사 업 5년의 성과와 발전방향, 동림기술관리센터, 2000), r C 농업과학기술의 좌표와 정책방향」 (한국농촌경제연구원, 2000), 「 |2회 과학기술예 측: 한국의 미래기술, 나학기술정책연구원, 한 국과학기술평가원, 1999) 등을 검토하여 유망한 기술로 선정되어 있는 기술을 수집하였다. 이 와 동시에 미래유망기술에 대한 수요조사도 실 시하였다. 이 조사표에는 분야명, 기술명, 필요 성 및 연구개발의 목표가 작성되도록 하였다. 기술개발 수요조사는 이 분야의 산. . I 전 문가를 대상으로 이메일을 사용하여 실시하였 다.

이를 통해 수집된 기술은 14 명의 산 · · I 전문가를 엄선하여 전문위원회를 구성하고, 그 들로 하여금 수집 분류된 기술을 검토하도록 하였다. 이때, 분야내 중분류를 설정하여 수집 된 기술을 해당 중분류 영역으로 분류시키고, 중분류별로 기술간 가능한 한 상호독립성을 유 지하면서 조정하도록 하되, 중복 및 유사기술 을 통합 또는 삭제하도록 하였다. 나아가, 중분 야별로 제안되지 않았지만 중요하다고 판단되 는 기술을 첨가시키도록 하였다. 이러한 과정 을 통하여 델파이 조사를 위한 대안으로서 최 종 기술을 확정하였다.

본 연구를 위한 축산수의분야의 최종 기술은 Fig. 1과 같이 90개로서 '번식' 14개, '유전육종' 12 개, ‘질병/방역' 15 개, ‘영양사료' 15 개, ‘육가 공' 13 개, ‘유가공' 11 개, ‘위생’ 10 개로 분류되었 다.

모두 62명의 응답자중 40 세 연령계층이 37 명으로 전체 응답자의 $60 \%$ 를 차지했고, 이어

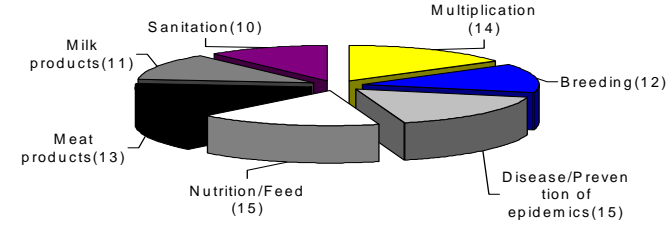

Fig. 1. Numbers of future core technologies by fields in Animal Science and Veterinary Medicine.

서 50 세 연령계층이 20명으로 $32 \%$ 를 차지 했다. 연구경력 기간은 20 년이 전체의 $45 \%$ 를 차지했으며, 이어서 10 년이 35\%를 차지 했다. 응답자 전원이 박사학위를 소지하고 있 으며, 연구원 15 명, 기업 4명, 대학이 43 명으로 대학교수가 전체의 $69 \%$ 를 차지했다. 설문응답 자의 분포를 정리하면 Table 1 과 같다.

\section{III 미래유망기술예측 조사결과}

\section{1. 미래유망기술의 실현시기}

미래유망기술의 실현시기는 1 차, 2 차 설문결 과를 순서대로 배열하여, 전체 응답자료 순서 통계량의 $1 / 4(25 \%)$ 에 해당하는 연도가 下四分 位數 中位數 (median), 그리고 3/4(75\%)에 해당하는 연도가 上四分位數 ⺊ 된다. 일반적으로 예측실현연도 는 응답분포의 중앙에 위치하는 중위수로 산출 하지만, 예측의 실현시기는 분포로 이해하는 것이 바람직하다. 즉, 실현시기 예측에 있어서 응답한 전문가의 절반은 중위수 연도 이전에 나머지 절반은 중위수 연도 이후에 기술이 실

Table 1. Distribution of respondent for questionnaire

\begin{tabular}{|c|c|c|c|c|c|c|c|c|c|c|c|}
\hline \multirow{2}{*}{ Respondent } & & \multirow{2}{*}{ Sub-total } & \multicolumn{4}{|c|}{ Year } & \multicolumn{5}{|c|}{ Experience } \\
\hline & & & 30 39 & $40 \sim 49$ & 50 59 & $60 \sim$ & $0 \sim 9$ & $10 \sim 19$ & $20 \sim 29$ & 30 39 & $40 \sim$ \\
\hline $\begin{array}{c}\text { Research } \\
\text { Institute }\end{array}$ & Ph.D. & 15 & & 12 & 3 & & & & 9 & 1 & \\
\hline Firm & Ph.D. & 4 & & 2 & 2 & & & 2 & 2 & & \\
\hline College & Ph.D. & 43 & 4 & 23 & 15 & 1 & 5 & 15 & 17 & 6 & \\
\hline \multicolumn{2}{|c|}{ Total } & 62 & 4 & 37 & 20 & 1 & 5 & 22 & 28 & 7 & 0 \\
\hline
\end{tabular}


현될 것으로 예측하였다는 점을 참고할 필요가 있다. 응답자가 5명 이하인 기술은 예측의 신 뢰성을 제고를 위해 분석대상에서 제외하였다.

실현시기 예측조사 결과, Table 2와 같이 90 개 기술 모두 2014년까지는 실현될 수 있는 것 으로 나타났다. 국내 실현시기와 세계실현시기 의 분포는 Fig. 2 와 같이 나타났다. 먼저 국내 실현시기를 비교하면, 총 90 개 기술 중 $70 \%$ 가 앞으로 5년 이내에 실현될 것으로 예측되었다. 세계실현시기는 $90 \%$ 의 기술이 5 년 이내에 실 현될 것으로 예측되었다.

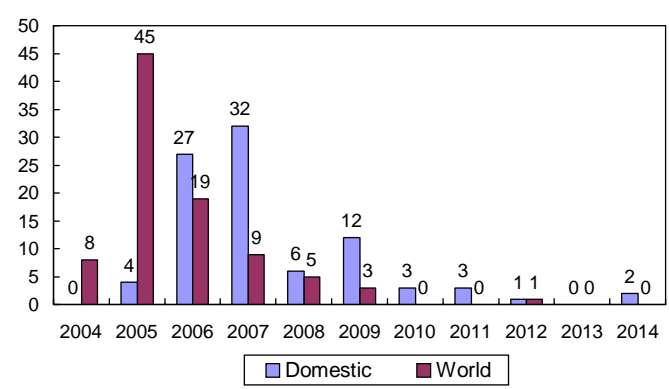

Fig. 2. Distribution of realization time by countries.

Table 2. Result of forecasting realization time by each technology

\begin{tabular}{|c|c|c|c|c|}
\hline $\begin{array}{l}\text { Realization } \\
\text { year in } \\
\text { Domestic(A) }\end{array}$ & $\begin{array}{l}\text { Tech. } \\
\text { No. }\end{array}$ & Technology & $\begin{array}{l}\text { Realization } \\
\text { year in } \\
\text { world(B) }\end{array}$ & $\begin{array}{l}\text { A-B } \\
(\mathrm{yr} .)\end{array}$ \\
\hline \multirow{4}{*}{2005} & 14 & $\begin{array}{l}\text { Developing of early pregnancy diagnosis technology for } \\
\text { animal }\end{array}$ & 2004 & 1 \\
\hline & 41 & Legislation of ethics provision for animal life & 2004 & 1 \\
\hline & 52 & Improving of evaluation method for feed value & 2004 & 1 \\
\hline & 81 & $\begin{array}{l}\text { Improving of application technology for preceding requisite } \\
\text { program and HACCP in medium and small sized works }\end{array}$ & 2004 & 1 \\
\hline \multirow{10}{*}{2006} & 1 & $\begin{array}{l}\text { Foundation building for reproduction technology for } \\
\text { characteristics transformation }\end{array}$ & 2005 & 1 \\
\hline & 2 & $\begin{array}{l}\text { Accomplished optimization of freezing technology for } \\
\text { generative cell }\end{array}$ & 2005 & 1 \\
\hline & 19 & $\begin{array}{l}\text { Developing of individual ID system and individual tracing } \\
\text { system for information-oriented application of domestic } \\
\text { livestock capability }\end{array}$ & 2005 & 1 \\
\hline & 25 & $\begin{array}{l}\text { Developing of capability examination system and selection } \\
\text { technology of superiority livestock using farm examination } \\
\text { information }\end{array}$ & 2005 & 1 \\
\hline & 27 & $\begin{array}{l}\text { Developing of disease diagnosis technology and vaccine } \\
\text { for economic animal, birds, and fishes }\end{array}$ & 2005 & 1 \\
\hline & 28 & $\begin{array}{l}\text { Developing of measurement technology for immune } \\
\text { response }\end{array}$ & 2005 & 1 \\
\hline & 33 & Developing of epidemiology method & 2005 & 1 \\
\hline & 46 & $\begin{array}{l}\text { Developing of utility increasing technology for traditional } \\
\text { feed resource }\end{array}$ & 2005 & 1 \\
\hline & 51 & System developing of coordinated feed quality management & 2005 & 1 \\
\hline & 61 & $\begin{array}{l}\text { Developing of wrapping method for fresh meat retail to } \\
\text { keep quality }\end{array}$ & 2005 & 1 \\
\hline
\end{tabular}




\begin{tabular}{|c|c|c|c|c|}
\hline $\begin{array}{c}\text { Realization } \\
\text { year in } \\
\text { Domestic(A) }\end{array}$ & $\begin{array}{l}\text { Tech. } \\
\text { No. }\end{array}$ & Technology & $\begin{array}{c}\text { Realization } \\
\text { year in } \\
\text { world(B) } \\
\end{array}$ & $\begin{array}{l}\text { A-B } \\
\text { (yr.) }\end{array}$ \\
\hline \multirow{17}{*}{2006} & 62 & $\begin{array}{l}\text { Developing of packing material that has anti-oxidation } \\
\text { capability using functional material }\end{array}$ & 2005 & 1 \\
\hline & 63 & $\begin{array}{l}\text { Developing of packing method increased quality and safety } \\
\text { for cooked meat }\end{array}$ & 2005 & 1 \\
\hline & 65 & $\begin{array}{l}\text { Improving of quality valuation method for fresh and } \\
\text { product meat }\end{array}$ & 2004 & 2 \\
\hline & 66 & $\begin{array}{l}\text { Developing of taste valuation method for fresh and } \\
\text { product meat }\end{array}$ & 2005 & 1 \\
\hline & 68 & $\begin{array}{l}\text { Developing of automatic system for quality valuation of } \\
\text { egg }\end{array}$ & 2005 & 1 \\
\hline & 71 & $\begin{array}{l}\text { Technology developing of selection, mass production, and } \\
\text { making seed ferment for lactic ferments }\end{array}$ & 2005 & 1 \\
\hline & 74 & $\begin{array}{l}\text { Developing of separation, refining, and production } \\
\text { technology for milk ingredient }\end{array}$ & 2005 & 1 \\
\hline & 76 & $\begin{array}{l}\text { Developing of analyzing and confirmation technology for } \\
\text { milk ingredient }\end{array}$ & 2005 & 1 \\
\hline & 79 & Developing of rapid quality valuation technology for milk & 2005 & 1 \\
\hline & 80 & Food developing of utility increasing for milk & 2005 & 1 \\
\hline & 82 & $\begin{array}{l}\text { Application of Microbial Quantitative Risk Assessment } \\
\text { technology in domestic apply }\end{array}$ & 2004 & 2 \\
\hline & 84 & $\begin{array}{l}\text { Developing of predictive model for microbial contam- } \\
\text { ination }\end{array}$ & 2005 & 1 \\
\hline & 85 & $\begin{array}{l}\text { Developing of feed management and decreasing microbial } \\
\text { contamination technology }\end{array}$ & 2005 & 1 \\
\hline & 86 & $\begin{array}{l}\text { Development of risk assessment model for livestock prod- } \\
\text { uct }\end{array}$ & 2004 & 2 \\
\hline & 87 & $\begin{array}{l}\text { Developing of risk analysis and risk management program } \\
\text { for livestock production }\end{array}$ & 2005 & 1 \\
\hline & 88 & $\begin{array}{l}\text { Developing of risk analysis and sanitation management } \\
\text { program for processing, marketing, and selling of livestock }\end{array}$ & 2004 & 2 \\
\hline & 90 & $\begin{array}{l}\text { Construction of risk management and communication sys- } \\
\text { tem }\end{array}$ & 2005 & 1 \\
\hline \multirow{4}{*}{2007} & 13 & Developing of discrimination technology for animal sex & 2005 & 2 \\
\hline & 23 & $\begin{array}{l}\text { Developing of conservation and utilization technology for } \\
\text { inheritance resource of traditional livestock }\end{array}$ & 2006 & 1 \\
\hline & 29 & Material developing for immunity augmentation & 2006 & 1 \\
\hline & 30 & $\begin{array}{l}\text { Discrimination technology developing of virus contamina- } \\
\text { tion to cell for vaccine production and vaccine }\end{array}$ & 2006 & 1 \\
\hline
\end{tabular}


Cho et al. ; Technology Forecasting using Delphi

\begin{tabular}{|c|c|c|c|c|}
\hline $\begin{array}{c}\text { Realization } \\
\text { year in } \\
\text { Domestic(A) }\end{array}$ & $\begin{array}{l}\text { Tech. } \\
\text { No. }\end{array}$ & Technology & $\begin{array}{c}\text { Realization } \\
\text { year in } \\
\text { world(B) } \\
\end{array}$ & $\begin{array}{l}\text { A-B } \\
\text { (yr.) }\end{array}$ \\
\hline & 31 & $\begin{array}{l}\text { Developing of animal medical supplies and analyzing } \\
\text { technology }\end{array}$ & 2005 & 2 \\
\hline & 32 & Developing of management technology for zoonosis & 2006 & 1 \\
\hline & 34 & $\begin{array}{l}\text { Developing of disease diagnosis technology and disease } \\
\text { model for lab. animal }\end{array}$ & 2006 & 1 \\
\hline & 36 & $\begin{array}{l}\text { Developing of genomics and proteomics for infectious } \\
\text { microcosme }\end{array}$ & 2007 & 0 \\
\hline & 38 & $\begin{array}{l}\text { Developing of disease diagnosis, treatment technology, and } \\
\text { vaccine for companion animal }\end{array}$ & 2006 & 1 \\
\hline & 42 & $\begin{array}{l}\text { Explanation of utilization path and developing of appli- } \\
\text { cation technology for animal nutrition }\end{array}$ & 2005 & 2 \\
\hline & 43 & $\begin{array}{l}\text { Setting and revision of nutritional requirement by animal } \\
\text { including specific animal }\end{array}$ & 2005 & 2 \\
\hline & 44 & $\begin{array}{l}\text { Developing of modelling technique for decision of nu- } \\
\text { tritional requirement and maximization of productivity }\end{array}$ & 2006 & 1 \\
\hline & 45 & $\begin{array}{l}\text { Developing of high quality and functional livestock prod- } \\
\text { uct }\end{array}$ & 2005 & 2 \\
\hline & 47 & Developing and utilization of non-traditional feed resource & 2005 & 2 \\
\hline \multirow[t]{11}{*}{2007} & 49 & $\begin{array}{l}\text { Developing of material that improves productivity and sub- } \\
\text { stitutes antibiotics }\end{array}$ & 2005 & 2 \\
\hline & 50 & $\begin{array}{l}\text { Developing of feed additive made by functional new mate- } \\
\text { rial }\end{array}$ & 2005 & 2 \\
\hline & 53 & $\begin{array}{l}\text { Developing of nutritional feeding method by environmental } \\
\text { friend }\end{array}$ & 2005 & 2 \\
\hline & 54 & Setting of raising model for organic livestock & 2005 & 2 \\
\hline & 56 & $\begin{array}{l}\text { Accomplished of decision and dangerous examination for } \\
\text { GMO feed }\end{array}$ & 2005 & 2 \\
\hline & 57 & $\begin{array}{l}\text { Preparing to decreasing plans of remained chemicals and } \\
\text { antibiotics for fresh meat and meat products }\end{array}$ & 2005 & 2 \\
\hline & 58 & $\begin{array}{l}\text { Preparing plans to survey quality change and to increase } \\
\text { preservative for fresh meat by radiation examination }\end{array}$ & 2005 & 2 \\
\hline & 59 & $\begin{array}{l}\text { Developing increasing technology for meat products pro- } \\
\text { ductivity using functional meat protein }\end{array}$ & 2006 & 1 \\
\hline & 60 & $\begin{array}{l}\text { Developing of quality increasing technology for meat prod- } \\
\text { ucts by adding health functional material }\end{array}$ & 2005 & 2 \\
\hline & 64 & $\begin{array}{l}\text { Developing of packing material of fresh meat and meat } \\
\text { products for radiation examination }\end{array}$ & 2005 & 2 \\
\hline & 67 & $\begin{array}{l}\text { Developing of automation system for carcass quality valu- } \\
\text { ation }\end{array}$ & 2005 & 2 \\
\hline
\end{tabular}




\begin{tabular}{|c|c|c|c|c|}
\hline $\begin{array}{l}\text { Realization } \\
\text { year in } \\
\text { Domestic(A) }\end{array}$ & $\begin{array}{l}\text { Tech. } \\
\text { No. }\end{array}$ & Technology & $\begin{array}{l}\text { Realization } \\
\text { year in } \\
\text { world(B) }\end{array}$ & $\begin{array}{l}\text { A-B } \\
\text { (yr.) }\end{array}$ \\
\hline \multirow{7}{*}{2007} & 70 & $\begin{array}{l}\text { Close examination of symbiosis and transmission mech- } \\
\text { anism between lactic ferments and host }\end{array}$ & 2006 & 1 \\
\hline & 72 & $\begin{array}{l}\text { Technology developing of metabolism product utilization } \\
\text { and characteristics improvement for lactic ferments }\end{array}$ & 2005 & 2 \\
\hline & 73 & $\begin{array}{l}\text { Developing of verification technology for function and } \\
\text { safety of lactic ferments }\end{array}$ & 2005 & 2 \\
\hline & 75 & $\begin{array}{l}\text { Developing of functional research technology for lactic } \\
\text { ferments }\end{array}$ & 2005 & 2 \\
\hline & 78 & $\begin{array}{l}\text { Developing of new processing technology for increasing } \\
\text { quality characteristic and preservation of milk products }\end{array}$ & 2006 & 1 \\
\hline & 83 & $\begin{array}{l}\text { Developing of epidemiological characteristic analysis, trac- } \\
\text { ing contamination source, and management technology } \\
\text { using molecular biological technology }\end{array}$ & 2005 & 2 \\
\hline & 89 & $\begin{array}{l}\text { Construction of hazards identification and database for } \\
\text { food }\end{array}$ & 2005 & 2 \\
\hline \multirow{6}{*}{2008} & 3 & $\begin{array}{l}\text { Technology developing of breeding efficiency increasing } \\
\text { for animal }\end{array}$ & 2006 & 2 \\
\hline & 24 & $\begin{array}{l}\text { Developing of establishment, operation, and application } \\
\text { technology for animal gene bank }\end{array}$ & 2006 & 2 \\
\hline & 37 & $\begin{array}{l}\text { Developing of disease diagnosis, remedy technology, and } \\
\text { vaccine for wild animal }\end{array}$ & 2006 & 2 \\
\hline & 48 & Developing and utilization of feed resource in abroad & 2006 & 2 \\
\hline & 55 & Developing of feed and raising system for animal welfare & 2005 & 3 \\
\hline & 77 & $\begin{array}{l}\text { Developing of allergy diminishing technology induced by } \\
\text { milk ingredients }\end{array}$ & 2006 & 2 \\
\hline \multirow{7}{*}{2009} & 4 & $\begin{array}{l}\text { Developing of utilization technology and establishing stem } \\
\text { cell of animal germ }\end{array}$ & 2006 & 3 \\
\hline & 5 & Developing of breeding technology for rare animal & 2007 & 2 \\
\hline & 6 & $\begin{array}{l}\text { Developing of effective revelation eradication and detection } \\
\text { technology for animal gene }\end{array}$ & 2007 & 2 \\
\hline & 15 & $\begin{array}{l}\text { Finding of DNA signal factor related with major economic } \\
\text { characteristics, and drawing gene map for livestock }\end{array}$ & 2006 & 3 \\
\hline & 17 & $\begin{array}{l}\text { Developing of identification technology for characteristics } \\
\text { of living livestock and superior livestock using non- } \\
\text { destruction examination method }\end{array}$ & 2006 & 3 \\
\hline & 18 & $\begin{array}{l}\text { Developing of functional gene detection technology related } \\
\text { with economic characteristics for livestock }\end{array}$ & 2007 & 2 \\
\hline & 20 & $\begin{array}{l}\text { Developing of functional singular protein identification } \\
\text { technology using animal proteome analysis }\end{array}$ & 2007 & 2 \\
\hline
\end{tabular}


Cho et al. ; Technology Forecasting using Delphi

\begin{tabular}{|c|c|c|c|c|}
\hline $\begin{array}{c}\text { Realization } \\
\text { year in } \\
\text { Domestic(A) }\end{array}$ & $\begin{array}{l}\text { Tech. } \\
\text { No. }\end{array}$ & Technology & $\begin{array}{c}\text { Realization } \\
\text { year in } \\
\text { world(B) }\end{array}$ & $\begin{array}{l}\text { A-B } \\
\text { (yr.) }\end{array}$ \\
\hline \multirow{5}{*}{2009} & 21 & $\begin{array}{l}\text { Developing of analyzing technology for livestock heredity } \\
\text { capability using bio-information technology }\end{array}$ & 2007 & 2 \\
\hline & 22 & $\begin{array}{l}\text { Developing of bio-information analyzing technology for } \\
\text { gene search related with livestock economic characteristics }\end{array}$ & 2007 & 2 \\
\hline & 35 & Utility gene search using knock-out technology & 2007 & 2 \\
\hline & 39 & $\begin{array}{l}\text { Developing of engineering technology for veterinary medi- } \\
\text { cine }\end{array}$ & 2007 & 2 \\
\hline & 69 & $\begin{array}{l}\text { Examining of relationship between gene indication and } \\
\text { meat quality }\end{array}$ & 2006 & 3 \\
\hline \multirow{3}{*}{2010} & 10 & $\begin{array}{l}\text { Utility of production technology for secretion animal of } \\
\text { medical supplies }\end{array}$ & 2008 & 2 \\
\hline & 11 & Utility of reproduction technology for somatic cell & 2008 & 2 \\
\hline & 40 & Developing of application technology for xenotransplantation & 2009 & 1 \\
\hline \multirow{3}{*}{2011} & 7 & $\begin{array}{l}\text { Utility of production technology for characteristics conver- } \\
\text { sion animal }\end{array}$ & 2008 & 3 \\
\hline & 8 & $\begin{array}{l}\text { Establishment of multiplication and maintaining technology } \\
\text { for characteristics conversion animal }\end{array}$ & 2008 & 3 \\
\hline & 26 & $\begin{array}{l}\text { Developing of functional animal breeding technology using } \\
\text { gene transition technology }\end{array}$ & 2009 & 2 \\
\hline 2012 & 16 & $\begin{array}{l}\text { Developing of molecular breeding technology of animal } \\
\text { using utility gene search technology }\end{array}$ & 2008 & 4 \\
\hline \multirow{2}{*}{2014} & 9 & $\begin{array}{l}\text { Developing of production technology for animal that } \\
\text { provides organs between different kind of animal }\end{array}$ & 2009 & 5 \\
\hline & 12 & $\begin{array}{l}\text { Developing of solution for deformity by embryology for } \\
\text { reproduction animal }\end{array}$ & 2011 & 3 \\
\hline
\end{tabular}

\section{2. 미래유망기술의 중요도와 연구개발수준}

번식 영역에서는 '이종장기제공동물 생산기 술이 개발된다’의 기술이 중요도지수 82.89로 가장 높게 나타났다. 번식 영역의 중요도지수 상위 5 개 기술은 Table 3 과 같다.

유전육종 영역에서는 '가축의 주요 경제형질 연 관 DNA 표지인자 발굴 및 유전자 지도가 작성된 다'의 기술이 중요도지수 81.78로 가장 높게 나타 났으나, 세계기술수준과 비교하여 국내기술수준은
상대적으로 낮은 것으로 나타났다. 유전육종 영역 의 중요도지수 상위 5 개 기술은 Table 4 와 같다. 질병/방역 영역에서는 '인수공통전염병 관리 기술이 개발된다'의 기술이 중요도지수 81.45 로 가장 높게 나타났다. 질병/방역 영역의 중요도 지수 상위 5 개 기술은 Table 5 와 같다.

영양사료 영역에서는 '항생제 대체 생산성향 상제가 개발된다'의 기술이 중요도지수 75 로 가장 높게 나타났다. 영양사료 영역의 중요도 지수 상위 5개 기술은 Table 6과 같다. 
Table 3. Top 5 technologies for field of Multiplication

\begin{tabular}{cllcc}
\hline \multicolumn{1}{c}{ Rank } & \multicolumn{1}{c}{ Technology } & $\begin{array}{c}\text { Important } \\
\text { Index }\end{array}$ & $\begin{array}{c}\text { R\&D level in } \\
\text { Korea(\%) }\end{array}$ \\
\hline \hline 1 & $\begin{array}{l}\text { Developing of production technology for animal that provides } \\
\text { organs between different kind of animal }\end{array}$ & 82.89 & 43.51 \\
\hline 2 & $\begin{array}{l}\text { Utility of production technology for secretion animal of medical } \\
\text { supplies }\end{array}$ & 78.07 & 49.47 \\
\hline 3 & $\begin{array}{l}\text { Developing of utilization technology and establishing stem cell of } \\
\text { animal germ }\end{array}$ & 78.02 & 52.73 \\
\hline 4 & $\begin{array}{l}\text { Utility of production technology for characteristics conversion an- } \\
\text { imal }\end{array}$ & 74.56 & 47.93 \\
\hline & $\begin{array}{l}\text { Developing of effective revelation eradication and detection tech- } \\
\text { nology for animal gene. }\end{array}$ & 71.05 & 46.90 \\
\hline
\end{tabular}

Table 4. Top 5 technologies for field of breeding

\begin{tabular}{cllcc}
\hline Rank & \multicolumn{1}{c}{ Technology } & $\begin{array}{c}\text { Important } \\
\text { Index }\end{array}$ & $\begin{array}{c}\text { R\&D level in } \\
\text { Korea(\%) }\end{array}$ \\
\hline \hline 1 & $\begin{array}{l}\text { Finding of DNA signal factor related with major economic } \\
\text { characteristics, and drawing gene map for livestock }\end{array}$ & 81.78 & 42.71 \\
\hline 2 & $\begin{array}{l}\text { Developing of functional gene detection technology related with } \\
\text { economic characteristics for livestock }\end{array}$ & 75.00 & 45.08 \\
\hline 3 & $\begin{array}{l}\text { Developing of molecular breeding technology of animal using } \\
\text { utility gene search technology }\end{array}$ & 74.15 & 44.07 \\
\hline 4 & $\begin{array}{l}\text { Developing of establishment, operation, and application technology } \\
\text { for animal gene bank }\end{array}$ & 72.84 & 41.72 \\
\hline 5 & $\begin{array}{l}\text { Developing of analyzing technology for livestock heredity capa- } \\
\text { bility using bio-information technology }\end{array}$ & 71.61 & 42.37 \\
\hline
\end{tabular}

Table 5. Top 5 technologies for field of disease and prevention of epidemics

\begin{tabular}{clcc}
\hline Rank & \multicolumn{1}{c}{ Technology } & $\begin{array}{c}\text { Important } \\
\text { Index }\end{array}$ & $\begin{array}{c}\text { R\&D level in } \\
\text { Korea(\%) }\end{array}$ \\
\hline \hline 1 & Developing of management technology for zoonosis & 81.45 & 57.70 \\
\hline 2 & $\begin{array}{l}\text { Developing of disease diagnosis technology and vaccine for eco- } \\
\text { nomic animal, birds, and fishes }\end{array}$ & 78.75 & 57.74 \\
\hline 3 & Developing of animal medical supplies and analyzing technology & 72.95 & 56.07 \\
\hline 4 & Material developing for immunity augmentation & 72.18 & 53.33 \\
\hline 5 & Developing of genomics and proteomics for infectious microcosme & 66.10 & 47.54 \\
\hline
\end{tabular}


육가공 영역에서는 '신선육 및 육제품에서의 잔유 화학물질 및 항생물질 감소 방안이 마련 된다'의 기술이 중요도지수 74.51 로 가장 높게 나타났다. 육가공 영역의 중요도지수 상위 5 개 기술은 Table 7 과 같다.
유가공 영역에서는 ‘원유 신속 품질 판별 기술 이 개발된다’의 기술이 중요도지수 60.66으로 가 장 높게 나타났으나, 전체적으로 타 영역과 비교 하여 중요도지수가 낮게 나타났다. 유가공 영역 의 중요도지수 상위 5 개 기술은 Table 8 과 같다.

Table 6. Top 5 technologies for field of nutrition and feed

\begin{tabular}{clccc}
\hline Rank & \multicolumn{1}{c}{ Technology } & $\begin{array}{c}\text { Important } \\
\text { Index }\end{array}$ & $\begin{array}{c}\text { R\&D level in } \\
\text { Korea(\%) }\end{array}$ \\
\hline \hline 1 & $\begin{array}{l}\text { Developing of material that improves productivity and substitutes } \\
\text { antibiotics }\end{array}$ & 75.00 & 50.00 \\
\hline 2 & Developing of feed additive made by functional new material & 70.56 & 52.70 \\
\hline 3 & Developing of high quality and functional livestock product & 70.08 & 58.73 \\
\hline 4 & $\begin{array}{l}\text { Accomplished of decision and dangerous examination for GMO } \\
\text { feed }\end{array}$ & 63.49 & 48.06 \\
\hline 5 & Developing of feed additive made by functional new material & 62.30 & 54.19 \\
\hline
\end{tabular}

Table 7. Top 5 technologies for field of meat products

\begin{tabular}{cllccc}
\hline Rank & \multicolumn{2}{c}{ Technology } & $\begin{array}{c}\text { Important } \\
\text { Index }\end{array}$ & $\begin{array}{c}\text { R\&D level in } \\
\text { Korea(\%) }\end{array}$ \\
\hline \hline 1 & $\begin{array}{l}\text { Preparing to decreasing plans of remained chemicals and } \\
\text { antibiotics for fresh meat and meat products }\end{array}$ & 74.51 & 54.23 \\
\hline 2 & Developing of automation system for carcass quality valuation & 67.08 & 52.67 \\
\hline 3 & $\begin{array}{l}\text { Developing of wrapping method for fresh meat retail to keep } \\
\text { quality }\end{array}$ & 55.83 & 61.36 \\
\hline 4 & $\begin{array}{l}\text { Improving of quality valuation method for fresh and product meat } \\
5\end{array}$ & $\begin{array}{l}\text { Examining of relationship between gene indication and meat } \\
\text { quality }\end{array}$ & 55.42 & 61.03 \\
\hline
\end{tabular}

Table 8. Top 5 technologies for field of milk products

\begin{tabular}{clcc}
\hline Rank & \multicolumn{1}{c}{ Technology } & $\begin{array}{c}\text { Important } \\
\text { Index }\end{array}$ & $\begin{array}{c}\text { R\&D level in } \\
\text { Korea(\%) }\end{array}$ \\
\hline \hline 1 & Developing of rapid quality valuation technology for milk & 60.66 & 63.28 \\
\hline 2 & Food developing of utility increasing for milk & 57.79 & 64.59 \\
\hline $3 \quad \begin{array}{l}\text { Developing of allergy diminishing technology induced by milk } \\
\text { ingredients }\end{array}$ & 57.50 & 49.33 \\
\hline 4 & $\begin{array}{l}\text { Developing of verification technology for function and safety of } \\
\text { lactic ferments }\end{array}$ & 55.33 & 60.00 \\
\hline 5 & $\begin{array}{l}\text { Technology developing of selection, mass production, and making } \\
\text { seed ferment for lactic ferments }\end{array}$ & 54.10 & 62.00 \\
\hline
\end{tabular}


위생 영역에서는 ‘위해미생물 정량적 위험평 가(Microbial Quantitative Risk Assessment) 기술 의 국내적용에 활용된다'의 기술이 중요도지수 72.95로 가장 높게 나타났다. 위생 영역의 중요 도지수 상위 5 개 기술은 Table 9와 같다.

미래유망기술의 중요도지수를 적용하여 축산
수의분야의 8 개의 중분류를 비교하여 보면, Fig. 3과 같다. 유전육종이 69.07로 가장 높았 고, 번식, 위생, 질병 및 방역, 영양사료, 유가 공, 육가공 순으로 나타났다. 축산수의분야의 전체평균은 62.13로 나타났다.

연구개발수준은 Fig. 4와 같이 선진국과 비교

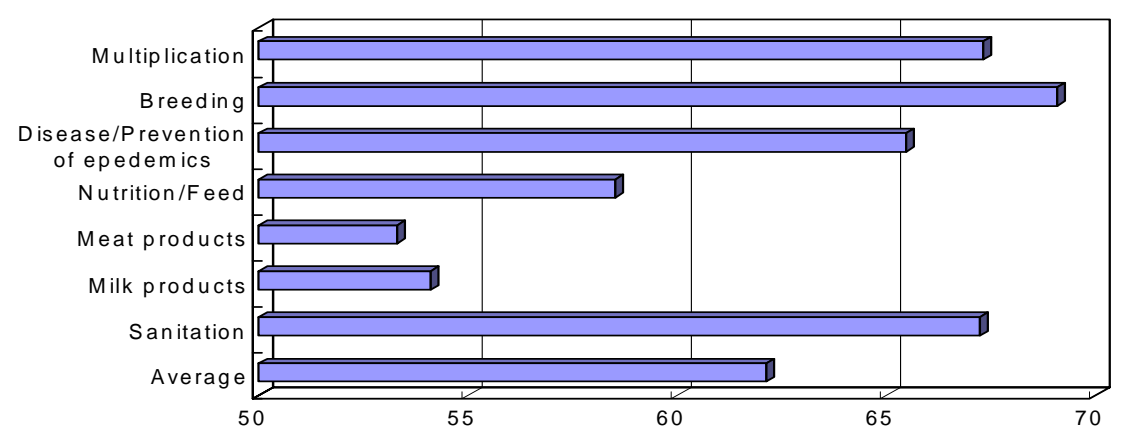

Fig. 3. Importance index by fields.

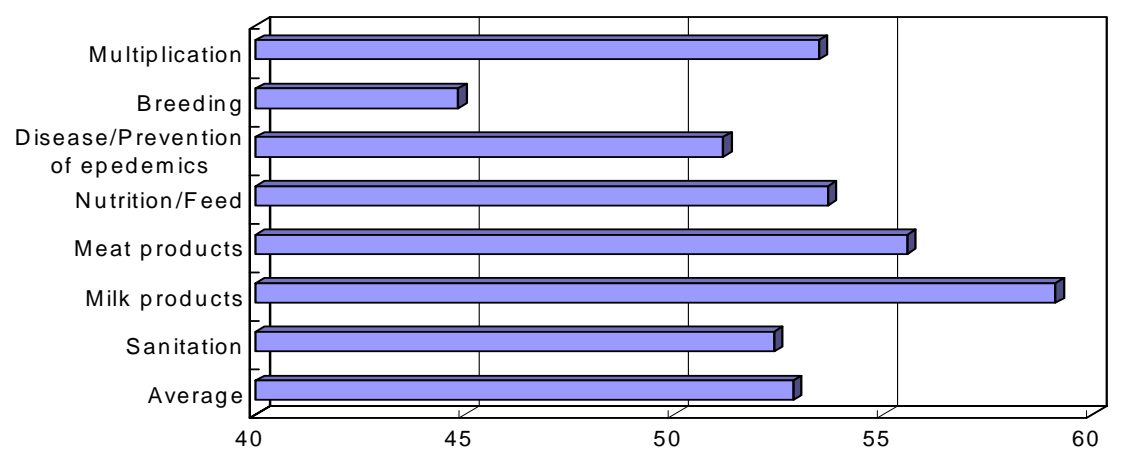

Fig. 4. R\&D level by fields.

Table 9. Top 5 technologies for field of sanitation

\begin{tabular}{clccc}
\hline Rank & \multicolumn{1}{c}{ Technology } & $\begin{array}{c}\text { Important } \\
\text { Index }\end{array}$ & $\begin{array}{c}\text { R\&D level in } \\
\text { Korea(\%) }\end{array}$ \\
\hline \hline 1 & $\begin{array}{l}\text { Application of Microbial Quantitative Risk Assessment technology } \\
\text { in domestic apply }\end{array}$ & 72.95 & 51.94 \\
\hline 2 & $\begin{array}{l}\text { Improving of application technology for preceding requisite } \\
\text { program and HACCP in medium and small sized works }\end{array}$ & 72.54 & 57.42 \\
\hline 3 & $\begin{array}{l}\text { Developing of risk analysis and risk management program for } \\
\text { livestock production }\end{array}$ & 70.42 & 54.10 \\
\hline 4 & $\begin{array}{l}\text { Developing of risk analysis and sanitation management program } \\
\text { for processing, marketing, and selling of livestock }\end{array}$ & 69.92 & 52.79 \\
\hline 5 & $\begin{array}{l}\text { Developing of epidemiological characteristic analysis, tracing } \\
\text { contamination source, and management technology using molecular } \\
\text { biological technology }\end{array}$ & 68.85 & 50.65 \\
\hline
\end{tabular}


하여 평균 $52.85 \%$ 수준으로 평가되었다. 선진 국대비 기술수준이 다소 양호하게 나타난 영역 은 유가공 분야로 $59.12 \%$ 수준으로 예측되었 다. 연구개발수준이 가장 낮게 평가된 분야는 유전육종 분야로 선진국 대비 $44.84 \%$ 수준에
지나지 않아 이 분야의 기술수준 제고가 필요 한 것으로 나타났다.

구체적으로 연구개발수준이 비교적 높은 상

위 20 대 기술은 아래의 Table 10 과 같다.

Table 10. Top 20 technologies that have high R\&D level

\begin{tabular}{|c|c|c|}
\hline $\begin{array}{l}\text { Tech. } \\
\text { number }\end{array}$ & Technology & R\&D level \\
\hline 2 & Accomplished optimization of freezing technology for generative cell & 67.72 \\
\hline 14 & Developing of early pregnancy diagnosis technology for animal & 66.78 \\
\hline 76 & Developing of analyzing and confirmation technology for milk ingredient & 65.08 \\
\hline 1 & $\begin{array}{l}\text { Foundation building for reproduction technology for characteristics } \\
\text { transformation }\end{array}$ & 64.83 \\
\hline 80 & Food developing of utility increasing for milk & 64.59 \\
\hline 3 & Technology developing of breeding efficiency increasing for animal & 63.86 \\
\hline 79 & Developing of rapid quality valuation technology for milk & 63.28 \\
\hline 71 & $\begin{array}{l}\text { Technology developing of selection, mass production, and making seed } \\
\text { ferment for lactic ferments }\end{array}$ & 62.00 \\
\hline 46 & Developing of utility increasing technology for traditional feed resource & 61.94 \\
\hline 61 & Developing of wrapping method for fresh meat retail to keep quality & 61.36 \\
\hline 52 & Improving of evaluation method for feed value & 61.29 \\
\hline 65 & Improving of quality valuation method for fresh and product meat & 61.03 \\
\hline 74 & $\begin{array}{l}\text { Developing of separation, refining, and production technology for milk } \\
\text { ingredient }\end{array}$ & 61.00 \\
\hline 73 & $\begin{array}{l}\text { Developing of verification technology for function and safety of lactic } \\
\text { ferments }\end{array}$ & 60.00 \\
\hline 51 & System developing of coordinated feed quality management & 59.68 \\
\hline 63 & Developing of packing method increased quality and safety for cooked meat & 59.32 \\
\hline 85 & $\begin{array}{l}\text { Developing of feed management and decreasing microbial contamination } \\
\text { technology }\end{array}$ & 59.02 \\
\hline 60 & $\begin{array}{l}\text { Developing of quality increasing technology for meat products by adding } \\
\text { health functional material }\end{array}$ & 58.87 \\
\hline 45 & Developing of high quality and functional livestock product & 58.73 \\
\hline 75 & Developing of functional research technology for lactic ferments & 58.69 \\
\hline
\end{tabular}




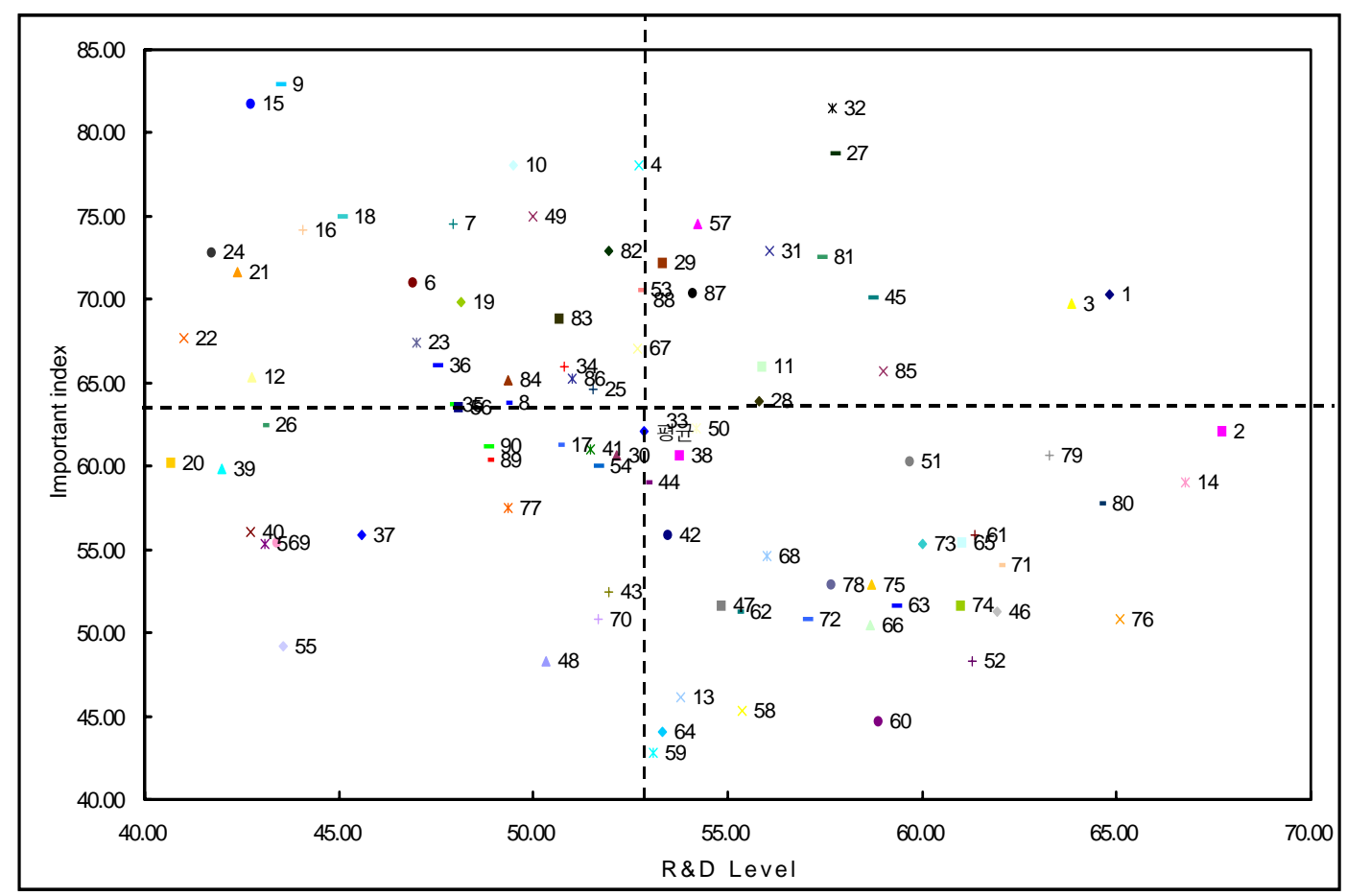

Fig. 5. Port-polio of technologies by importance index and R\&D level.

\section{3. 중요도와 연구개발수준 비교}

미래유망기술의 중요도와 연구개발수준을 분석함으로써 핵심전략기술을 발굴하기 위하 여 포트폴리오를 아래 Fig. 5와 같이 구성하 였다.

축산수의분야의 평균 연구개발수준은 $52.85 \%$ 이며, 평균 중요도지수는 62.13으로 나타났다. I ㅏㅜ부면에 해당하는 기술은 15 개로 가장 성장 잠재력이 높은 영역으로 나타났고, ㅍ 분면에 위치한 기술은 29 개로 중요도는 높으나 연구개 발 수준이 낮아 지속적인 투자가 요구는 영역 으로 평가되었다.

\section{4. 연구개발 추진방법}

연구개발 추진 방법에 대한 의견은 다음 Fig. 6과 같이 나타났다. 산학연협동이 $45 \%$, 정부주도가 $27 \%$, 민간주도가 $17 \%$, 국제공동 이 $11 \%$ 순으로 나타나, 산학연의 유기적 협
동에 의한 연구가 가장 요구되는 추진방법으 로 나타났다.

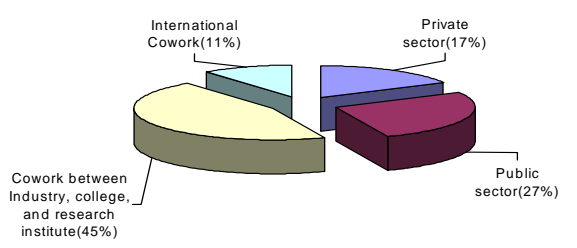

Fig. 6. Distribution for R\&D developer.

각 연구개발 주체별로 응답비율이 높은 기 술을 정리하면 Table 11 과 같다. 연구개발 주 체로서 가장 응답비율이 높게 나타난 것은 ‘산학협동'의 기술들로 ‘유성분의 기능성 연구 기술이 개발된다’는 총 응답자중 $62.5 \%$ 로부 터 산학협동으로 진행되어야 한다는 것으로 나타났다. 
Table 11. High ranked technologies by developer

\begin{tabular}{|c|c|c|c|}
\hline Developer & Number & Technology & Response \\
\hline \multirow{5}{*}{$\begin{array}{l}\text { Private } \\
\text { sector }\end{array}$} & 63 & $\begin{array}{l}\text { Developing of packing method increased quality and safety for } \\
\text { cooked meat }\end{array}$ & $38.24 \%$ \\
\hline & 60 & $\begin{array}{l}\text { Developing of quality increasing technology for meat products } \\
\text { by adding health functional material }\end{array}$ & $37.50 \%$ \\
\hline & 62 & $\begin{array}{l}\text { Developing of packing material that has anti-oxidation capa- } \\
\text { bility using functional material }\end{array}$ & $35.71 \%$ \\
\hline & 64 & $\begin{array}{l}\text { Developing of packing material of fresh meat and meat produc- } \\
\text { ts for radiation examination }\end{array}$ & $34.85 \%$ \\
\hline & 80 & Food developing of utility increasing for milk & $34.62 \%$ \\
\hline \multirow{5}{*}{$\begin{array}{l}\text { Public } \\
\text { sector }\end{array}$} & 41 & Legislation of ethics provision for animal life & $65.71 \%$ \\
\hline & 23 & $\begin{array}{l}\text { Developing of conservation and utilization technology for inher- } \\
\text { itance resource of traditional livestock }\end{array}$ & $59.09 \%$ \\
\hline & 24 & $\begin{array}{l}\text { Developing of establishment, operation, and application technolo- } \\
\text { gy for animal gene bank }\end{array}$ & $54.29 \%$ \\
\hline & 25 & $\begin{array}{l}\text { Developing of capability examination system and selection tech- } \\
\text { nology of superiority livestock using farm examination informa- } \\
\text { tion }\end{array}$ & $52.17 \%$ \\
\hline & 82 & $\begin{array}{l}\text { Application of Microbial Quantitative Risk Assessment technol- } \\
\text { ogy in domestic apply }\end{array}$ & $51.35 \%$ \\
\hline \multirow{5}{*}{$\begin{array}{c}\text { Cowork } \\
\text { between } \\
\text { industry, } \\
\text { college, } \\
\text { and } \\
\text { reswarch } \\
\text { institute }\end{array}$} & 75 & Developing of functional research technology for lactic ferments & $62.50 \%$ \\
\hline & 71 & $\begin{array}{l}\text { Technology developing of selection, mass production, and mak- } \\
\text { ing seed ferment for lactic ferments }\end{array}$ & $62.32 \%$ \\
\hline & 42 & $\begin{array}{l}\text { Explanation of utilization path and developing of application } \\
\text { technology for animal nutrition }\end{array}$ & $61.76 \%$ \\
\hline & 2 & $\begin{array}{l}\text { Accomplished optimization of freezing technology for gener- } \\
\text { ative cell }\end{array}$ & $61.54 \%$ \\
\hline & 73 & $\begin{array}{l}\text { Developing of verification technology for function and safety of } \\
\text { lactic ferments }\end{array}$ & $61.43 \%$ \\
\hline \multirow{5}{*}{$\begin{array}{l}\text { Internatio- } \\
\text { nal } \\
\text { cowork }\end{array}$} & 4 & $\begin{array}{l}\text { Developing of utilization technology and establishing stem cell } \\
\text { of animal germ }\end{array}$ & $32.35 \%$ \\
\hline & 6 & $\begin{array}{l}\text { Developing of effective revelation eradication and detection } \\
\text { technology for animal gene }\end{array}$ & $28.17 \%$ \\
\hline & 9 & $\begin{array}{l}\text { Developing of production technology for animal that provides } \\
\text { organs between different kind of animal }\end{array}$ & $26.87 \%$ \\
\hline & 21 & $\begin{array}{l}\text { Developing of analyzing technology for livestock heredity } \\
\text { capability using bio-information technology }\end{array}$ & $25.97 \%$ \\
\hline & 15 & $\begin{array}{l}\text { Finding of DNA signal factor related with major economic } \\
\text { characteristics, and drawing gene map for livestock }\end{array}$ & $25.68 \%$ \\
\hline
\end{tabular}




\section{5 정책수단}

정부의 정책수단에 대한 응답결과는 Fig. 7 과 같이 나타났다. '연구비 확충’이 $27 \%$, '인프라구 축’이 $26 \%$, ‘인력양성’이 $20 \%$ 로 세 정책수단의 합이 $70 \%$ 를 차지하고 있었으며, ‘협력교류'가 $17 \%$, ‘제도개선'과 기타가 각각 $8 \%, 2 \%$ 로 나타 났다. 즉, 축산 - =의분야의 미래유망기술을 실 현시키기 위해서는 연구비의 확충과 인프라 구 축이 가장 중요하며, 이에 못지 않게 인력양성 또한 중요한 것을 의미한다. 중장기적인 R\&D 프로그램의 개발로 연구비 지원, 인프라구축, 그리고 인력양성 등의 문제에 대한 다각적인 접근이 필요하다.

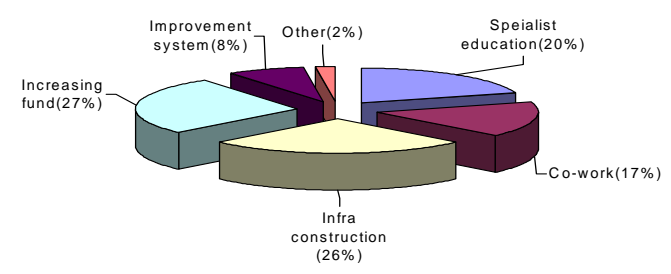

Fig. 7. Distribution for R\&D developing by policies.

\section{$\mathrm{IV}$ 결 론}

본 연구에서는 우리나라 농업을 21세기 고부 가가치의 전략핵심산업으로 발전시키기 위한 일환으로 축산 . =의분야 62 명의 산, 학, 연 전 문가를 대상으로 델파이조사를 실시하였다. 델 파이조사의 기초가 된 미래유망기술은 축산 . 수의분야의 전문가를 대상으로 실시한 기술수 요조사, 문헌을 중심으로 한 문헌조사, 축산 . 수의분야 14 명의 전문가로 구성이 된 전문위원 회를 통하여 90 개의 기술이 도출이 되었다. 이 델파이조사에서는 각 기술의 미래실현시기와 더불어 중요도와 연구개발수준 등에 대한 설문 조사를 실시하였다. 주요 결과를 살펴보면 다 음과 같다.

도출된 기술의 실현시기로는 90개의 기술 모 두 2014년까지 실현될 것으로 예측이 되었다. 이 중 $70 \%$ 기술이 앞으로 5 년 이내에 실현될
것으로 예측되었으며, 세계 실현시기는 $90 \%$ 가 5년 이내에 실현될 것으로 예측되었다.

기술의 중요도 지수를 중분류 영역별로 살펴 본 결과는 ‘유전육종' 영역이 69.07로 가장 높 게 나타났으며, 중분류별 연구개발 수준은 '유 가공, 영역이 $59.12 \%$ 로 가장 높게 나타났다. 중 요도와 연구개발수준을 함께 살펴본 결과 축 산 - =의분야에서 연구개발수준이 높고 중요도 도 높은 것으로 나타난 기술은 15 개 기술로 축 산 . =의분야의 기술 중 가장 성장 잠재력이 높은 기술로 나타났다.

연구개발 추진방법으로는 '산학연협동'이 $45 \%$ 로, 연구개발 주체 역시 ‘산학협동’이 가장 높 게 나타났다. 이 기술을 도달하기 위한 정책수 단으로는 ‘연구비 확충’이 $27 \%$, ‘인프라 구축’이 $26 \%$, ‘인력 양성’이 $20 \%$ 로 높게 나타나 중장기 적인 $\mathrm{R} \& \mathrm{D}$ 프로그램의 개발로 연구비 지원, 인 프라 구축, 그리고 인력 양성 등의 문제에 대 한 다각적인 접근이 필요하다.

이 조사를 통하여 중요도와 더불어 연구개발 수준이 높은 핵심기술을 도출해 내고 연구개발 추진방법, 정책수단 등이 도출되었다. 이러한 과정을 통하여 도출된 결과로 축산 - =의분야 의 육성발전을 위한 정책적 지원대상을 파악할 수 있게 되어 우리나라 축산 - =의분야의 연구 개발정책을 수립하는데 중요한 기초자료를 제 공하고 있다. 이와 함께 산. · ․ㅡ모두 고유 의 영역에서 이 기술을 이루기 위한 노력이 필 요하며, $\mathrm{R} \& \mathrm{D}$ 개발을 지원하는 정부와 민간부 문의 과감한 투자 역시 필요하다.

\section{$\mathrm{V}$ 감사의 글}

본 연구는 “미래 농업기술예측 - !드맵 작성 및 효율적인 투자기술 개발” 과제의 일환으로 이 루어졌습니다. 미래유망기술 예측을 위하여 미래 기술 수요조사 및 DELPHI 설문조사에 응하여 주 신 축산 ·

의분야의 미래기술 예측을 위한 전문위원회 위원 으로 참여하신 전문가께 감사를 드립니다. 본 연 구는 농림부 농림기술개발사업의 지원에 의하여 이루어진 것으로 지원에 감사를 드립니다. 


\section{$\mathrm{VI}$ 인 용 문 헌}

1. Linstone, H. A. and Turoff, M. 1975. The Delphi Method: Techniques and Applications, Addison-Wesley Publishing Company.

2. 과학기술정책연구원, 한국과학기술평가원. 1999. r 2회 과학기술예측: 한국의 미래기술,

3. 농림기술관리센터. 2000. '림기술개발사업 5년 의 성과와 발전방향,
4. 조근태. 1999. ‘ \&D의 예측과 결정, 자유아카 데미.

5. 조근태, 권철신. 2001. "기술예측에의 적용을 위 한 상호영향분석법의 이론적 고찰”, 기술혁신연 구, 9(1):95-120.

6. 한국농촌경제연구원. 2000. ㄷ농ㅇ업과학기술의 좌표와 정책방향,

(접수일자 : 2003. 12. 11. / 채택일자 : 2004. 4. 21.) 